\title{
An Examination of the Impact of Relative Age Effects and Academic Timing on Intercollegiate Athletics Participation in Women's Softball
}

\author{
Jess C. Dixon, Vincenzo Liburdi, Sean Horton, \\ and Patricia L. Weir \\ University of Windsor
}

\begin{abstract}
This investigation makes three noteworthy contributions to literature on the Relative Age Effect (RAE); 1) it adds to the small number of studies in women's sports, 2) it is one of very few papers to examine the RAE in intercollegiate athletics, and 3 ) it (re-)introduces "academic timing" to the discussion of RAEs in this context. The 50 top-ranked NCAA Division I women's softball teams at the conclusion of the 2011 season served as the focus for this investigation. Student-athletes were grouped into quartiles according to their birth date and identified as "on-time" or "academically delayed" based on their birth year and eligibility status. On-time student-athletes were over four times more likely to be born in quartile one than in quartile four, demonstrating a traditional RAE. This pattern was reversed for those who were academically delayed, with quartile four birth dates constituting more than half of the entire sample.
\end{abstract}

Keywords: relative age effect, academic timing, ntercollegiate athletics, women's softball, NCAA

The relative age effect (RAE) has been well-documented in the sport and educational psychology literatures. By definition, the RAE is a selection advantage that accrues to children born during the initial months of an age-defined cohort, providing them with developmental advantages over their younger counterparts (Barnsley, Thompson, \& Barnsley, 1985). Such advantages are likely to be present "when, for logistical reasons, children are grouped by age for school attendance or other activities where performance is strongly correlated with development" (Thompson, Barnsley, \& Dyck, 1999, p. 82). While originally intended to promote equality, fairness, and safety in the playing and/or learning environment (Barrow \& McGee, 1971; Barnsley \& Thompson, 1988; Vincent \& Glamser, 2006), the age-based grouping policies employed by many sport and educational development systems have had the unintended consequence of producing an unequal and unfair learning environment for athletes and students alike (Dixon, Horton, \& Weir, 2011). 
So intriguing has the RAE become in recent years that it was featured prominently within the opening chapter of Malcolm Gladwell's (2008) best-seller Outliers: The Story of Success, and was highlighted in a special issue of Sports Illustrated magazine on sport medicine's new frontiers (Levey, 2011). Perhaps most telling of all was a recent segment of the popular CBS television series 60 Minutes entitled "Redshirting: Holding kids back from kindergarten" (CBS Interactive, 2012), where the investigative journalists explored the social, psychological, and economic benefits (or detriments) of the RAE on North American youth.

In this study, we aim to expand what is known about the RAE by exploring its existence within the realm of women's intercollegiate softball. Despite the RAE having been evidenced within a variety of male sports, there are relatively few studies that have investigated the RAE in women's sports (Abel, Kruger, \& Pandya, 2011; Musch \& Grondin, 2001; Vincent \& Glamser, 2006; Weir, Smith, Paterson, $\&$ Horton, 2010). Given that previous research has demonstrated a significant RAE in men's baseball (e.g., Abel et al., 2011; Côté, Macdonald, Baker, \& Abernethy, 2006; Glamser \& Marciani, 1992; Thompson, Barnsley, \& Stebelsky, 1991, 1992), we were particularly interested in exploring whether that effect is mirrored in the women's game. In choosing to carry out this exploration within the context of women's intercollegiate softball, we make three noteworthy contributions to the RAE literature. First, we add to a growing literature related to the RAE in women's sports. Second, we provide one of the few investigations to examine the RAE in the realm of intercollegiate athletics. Lastly, we (re)introduce the issue of "academic timing" (Glamser \& Marciani, 1992) to the discussion of RAEs in the context of intercollegiate athletics.

\section{Conceptual Background}

Relative age differences in the developmental outcomes of children were first identified in the education system in the 1960s (Armstrong, 1966; Dickenson \& Larson, 1963; Freyman, 1965), but have since become quite pronounced within the realm of sport. Commencing with Grondin, Deshaies, and Nault (1984) and Barnsley et al.'s (1985) studies on Canadian male ice hockey players, research on the RAE in sport has proliferated, having been confirmed to exist within numerous sports (e.g., ice hockey, soccer, and baseball), at a multitude of competitive levels (e.g., recreational, competitive, representative, and elite), and in many different countries (for a comprehensive review of the RAE literature in sport, see Cobley, Baker, Wattie, \& McKenna, 2009a). Given the unique context in which this particular study was conducted (i.e., intercollegiate women's softball), having a background on the RAE in both educational and sport contexts is important.

Within the educational context, previous research has demonstrated in numerous countries that relatively older students achieve higher grades in a variety of subjects throughout elementary school, and that this advantage persists, although to a lesser degree, throughout secondary school and into university (Bedard \& Dhuey, 2006). While relatively older students are likely to be placed in "gifted" educational streams (Cobley et al., 2009b) and be selected for student leadership positions (e.g., student council president; Dhuey \& Lipscomb, 2008), those who are relatively younger are more likely to be retained for an additional year within 
the same grade (Elder \& Lubotsky, 2009), be designated for remedial instruction (Wallingford \& Prout, 2000), and/or be diagnosed with a learning disability (Martin, Foels, Clanton, \& Moon, 2004). The evidence clearly supports the notion "that children who experience the negative effects of a young relative age on school entry will experience both short- and long-term disadvantages at a higher rate than their age grouped older classmates" (Thompson et al., 1999, p. 83).

Within the sport context, relatively older children tend to be over-represented on elite teams in numerous sports, at virtually all competitive levels, and in multiple different countries (Cobley et al., 2009a). Due to their earlier physical, psychological, and emotional maturation, relatively older athletes begin outperforming their relatively younger counterparts on the field of play at a young age. In doing so, they are often selected to participate on elite teams where they are provided with advanced coaching, practice time, and competition (Cobley et al., 2009a). As such, the RAE becomes a "self-fulfilling prophecy" whereby those relatively older athletes who benefit from the initial advantage continue to reap the rewards of this advantage throughout the developmental period. On the contrary, the relatively younger athletes who are discriminated against in the selection process are more likely to receive negative feedback regarding their performance, demonstrate lower levels of self-perception, and ultimately withdraw from the activity altogether (Cobley et al., 2009b).

In general, greater effect sizes for the RAE are found within sport than in educational settings (Musch \& Grondin, 2001). One possible explanation for this result is that many educational districts have discontinued the streaming of children into gifted and/or remedial programs on the basis of their early academic performance (Allen \& Barnsley, 1993). An alternative explanation may be based on compulsory school attendance; while children have the flexibility of withdrawing from sport activities at their discretion, they are legislatively obligated to remain in school until they have reached a particular drop-out age (Musch \& Grondin, 2001). Regardless of the context, the overarching conclusion is the same: "children with a relative age advantage are more likely to succeed, while children with a relative age disadvantage are more likely to encounter problems in the particular activity for which they have been 'age grouped"' (Thompson et al., 1999, p. 83).

In addition to understanding the underlying mechanisms involved and the consequences associated with the RAE in both educational and sport settings, it is also important to comprehend how these effects may be moderated within the unique context of women's intercollegiate softball. Several moderating factors have been identified in the literature that may impact the extent of the RAE within this context, including the sex of the athlete, the intensity of the competition, and the selection process being used. In the following sections, we explore each of these moderators in detail.

\section{Sex}

The vast majority of RAE research in sport to date has been carried out using male samples (Abel et al., 2011; Musch \& Grondin, 2001; Vincent \& Glamser, 2006; Weir et al., 2010). In fact, Cobley et al. (2009a) revealed that only $2 \%$ of the samples used in their meta-analysis were comprised of female participants. Although this figure is likely to have increased in recent years, it remains somewhat unclear as to 
why women's sports have received such little attention in the RAE literature. Weir et al. (2009) pointed to "the lower value placed on women's sport in society as evidenced by the lack of opportunity to play at a professional level and in professional leagues compared to men" (Weir et al., 2010, p. 210). This argument holds that without professional (or other elite) playing opportunities, there is less competition for selection into advanced streams (or there is no streaming whatsoever) and thus, there is less likelihood of a RAE being present (Musch \& Grondin, 2001). Regardless of the rationale for this dearth in the literature, there is still much to be learned about the existence and patterning of the RAE in women's sports (Musch \& Grondin, 2001; Wattie, Cobley, \& Baker, 2008; Weir et al., 2010).

What little research has been done on women has yielded mixed results, with some studies showing a significant RAE (e.g., Delorme \& Raspaud, 2009b; Edgar \& O’Donoghue, 2005; Helsen, Van Winckel, \& Williams, 2005; Medic, Young, Starkes, Weir, \& Grove, 2009; Weir et al., 2010), others displaying no effect whatsoever (e.g., Abel et al., 2011; Delorme, Boiché, \& Raspaud, 2010; Delorme \& Raspaud, 2009a; Goldschmied, 2011; Vincent \& Glamser, 2006; Wattie, Baker, Cobley, \& Montelpare, 2007), and others showing an effect in some samples, but not in others (e.g., Baxter-Jones \& Helms, 1994). With very few exceptions (e.g., Delorme \& Raspaud, 2009b), stronger RAEs are typically found in male sports than female sports (Musch \& Grondin, 2001). Baxter-Jones (1995) reasoned that RAEs are higher in male sports because of the earlier maturation of girls and the higher variance in the maturity of boys during the selection period. Alternatively, Vincent and Glamser (2006) posited that the differences between girls and boys with respect to the RAE are a consequence of the desire by girls to conform to socially constructed gender roles. Thus, stereotyped definitions of femininity "could make early maturing females less motivated to achieve excellence in competitive sport because of a perception that society does not value female athletic accomplishments in the same way it does those of males" (Vincent \& Glamser, 2006, p. 412). Consequently, early maturing females (who are likely to be relatively older) may be more likely to drop-out of competitive sports to achieve and/or maintain status among their peers than those who are relatively younger (Shakib, 2003). A final argument, which is consistent with that offered for why there are not more RAE studies involving female samples in the first place, is that men's sports are generally more highly subscribed than women's sports, which results in there being greater competition for limited spots on elite teams (Musch \& Grondin, 2001).

\section{Intensity of Competition}

Some scholars have suggested that more popular the sport is and the more it is culturally valued, the greater the number of people who will be attracted to it, and consequently, youth are more likely to be streamlined at an early age based on their perceived talents (Cobley et al., 2009b; Musch \& Grondin, 2001). Given that competition is a necessary precondition for the RAE to exist, it should come as no surprise that Cobley et al. (2009a) found ice hockey $(32.8 \%)$, soccer (30\%), and baseball $(13 \%)$ to be the most frequently studied sport contexts within their meta-analysis on the RAE. With ice hockey being highly valued within Canada, and soccer being extremely popular within Europe and other parts of the world, the RAE has been found to be highly significant in both sports at all levels of competition 
(e.g., Helsen et al., 2005; Montelpare et al., 2000; Musch \& Hay, 1999; Wattie et al., 2007). Widely recognized as America's pastime, the sport of baseball has also received considerable attention within the RAE literature.

In their historical assessment of all Major League Baseball (MLB) players through the 1992 season, Grondin and Koren (2000) demonstrated that players born after the 1940s were found to have birthdates that were consistent with the RAE. These findings are supportive of other research that has confirmed the prevalence of the RAE throughout the youth (e.g., Thompson et al., 1992), collegiate (e.g., Glamser \& Marciani, 1992), and professional ranks (e.g., Abel et al., 2011; Côté et al., 2006; Thompson et al., 1991). Although researchers have expanded this line of inquiry to include other countries, such as Canada (Thompson et al., 1992) and Japan (Grondin \& Koren, 2000), to date, all but one of the RAE studies conducted within baseball have been delimited to male athletes.

Abel et al. (2011) examined the RAE among players in the All-American Girls Professional Baseball League (active from 1943 to 1954). With the distribution of players' birthdates from the first to fourth quartiles totaling 110, 95, 92, and 108, respectively, the authors failed to demonstrate a significant RAE within this population of athletes. In discussing their results, Abel et al. explained:

Because girls who became professional baseball players beginning in 1943 had no organizational youth baseball leagues, they were not subjected to the same organized structure with rigid cutoff dates for participation as boys.... Therefore the age restrictions which gave rise to a relative age effect for professional male baseball players did not exist for females. (p. 287)

However, much has changed since this time. Today, female baseball and softball players have well-structured leagues that they are able to compete in from the time they are toddlers right through to adults via Little League Softball and the Amateur Softball Association of America.

The sport of softball, in particular, has become so popular in recent decades that it has inspired the development of a number of professional leagues throughout the United States and abroad (National Pro Fastpitch, n.d.), albeit on more regional and less financially stable basis than their male equivalents. Women's softball was also introduced as an Olympic sport during the Atlanta Summer Games in 1996. However, the International Olympic Committee (IOC) has since voted women's softball, along with men's baseball, out of the Olympics (Associated Press, 2005). This being the case, with nearly 1,000 colleges and universities sponsoring the sport for more than 18,000 female student-athletes per year (Irick, 2011), the National Collegiate Athletic Association (NCAA) currently represents the pinnacle of organized elite softball competition in the United States. Thus, if a RAE were to be found within the context of women's softball, one might expect it to be found within the context of intercollegiate athletics.

\section{The Selection Process}

Founded in 1906, the NCAA conducts 89 national championships in 23 sports across three divisions, and provides sporting opportunities to more than 400,000 student-athletes per year at more than 1,000 member institutions throughout the United States and parts of Canada (NCAA, 2012). Flowing out of the NCAA 
Constitution are numerous operating principles and by-laws related to the subjects of nondiscrimination, fairness and equity, among others (NCAA, 2011a). For instance, the NCAA's Principle of Competitive Equity states:

The structure and programs of the Association and the activities of its members shall promote opportunity for equity in competition to assure that individual student-athletes and institutions will not be prevented unfairly from achieving the benefits inherent in participation in intercollegiate athletics. (NCAA, 2011a, p. 5)

Despite the apparent concern for competitive equity within the NCAA, there remains a dearth of RAE research involving samples derived from the intercollegiate athletics context

Given that the RAE has shown to increase with skill level (Cobley et al., 2009a), and that intercollegiate athletics represents the most elite sport competition for many non-Olympic athletes in North America (Popp, Hums, \& Greenwell, 2009), it is somewhat perplexing that this context has been examined so infrequently. Consistent with the RAE research in women's sports, less than $2 \%$ of the studies included in Cobley et al.'s (2009a) meta-analysis were based on intercollegiate athletes, and only one of these were conducted in the sport of baseball.

Glamser and Marciani (1992) explored the RAE within the context of intercollegiate football and baseball using data retrieved from the 1989 media guides of two NCAA Division I state universities. To conduct their analyses, the authors had to expand the concept of relative age to account for the unique nature of sport in the educational setting. As noted previously, in most sport settings, youth are grouped according to their birthdate, using some predetermined cut-off (e.g., January 1) as the basis for distinguishing between age cohorts. However, since school sports are typically grouped by grade level, rather than the actual ages of participants, there can be large age disparities between players on the same team. Above and beyond the twelve month disparity that may typically exist for age-grouped sport activities, children may commence school at an older age, fail one or more grades, or be intentionally held back by parents in hopes of improving their career prospects. Thus, when student-athletes enter their first year of university, the potential exists for there to be even greater age disparities than would typically exist within other age-grouped cohorts. In their analysis, Glamser and Marciani revealed that nearly half $(45 \%)$ of the athletes in their study were "academically delayed" by one or more years, which was over-representative of the overall student population at that time. Moreover, while the birthdates of the athletes they examined were equally distributed throughout the year, thereby suggesting that the RAE was not a factor, this was no longer the case once "academic timing" was taken into consideration.

Academic timing (AT) is the term that Glamser and Marciani (1992) used to explain the influence that an athlete's academic status or grade level has, over and above the effect of the athlete's birthdate, on his or her participation and/or success in school-based sports. For instance, assuming that students enter kindergarten at five years of age and do not skip or fail any grades along the way, the 2013 incoming class of university students ought to have been born in 1995. Similarly, university students entering their sophomore, junior, and senior years in 2013 ought to have been born in 1994, 1993, and 1992, respectively. Students who enter university 
with their age-grouped cohort are said to be "on-time," while those who enter university with a younger age-grouped cohort, regardless of the rationale for doing so, are deemed to be academically delayed. ${ }^{1}$ For each year that a student-athlete is academically delayed, she or he gains an additional 12 months of physical and psychological strength and maturation that can translate into better performance on the playing field.

Beyond the aforementioned reasons for why a student-athlete may become academically delayed upon entering university, some high school students (particularly males) will take a "victory lap" by voluntarily returning to high school for a fifth year. While the reasons for doing so are varied, continued participation in extracurricular activities, most notably sports, a perceived lack of maturity to proceed to university, and a need or desire to upgrade one's academic standing appear to be the most likely explanations (Brady \& Allingham, 2010). As an alternative to repeating one's senior year of high school, some students may choose to attend junior college after concluding high school to help reduce the "transition anxiety" (Sanders \& Burton, 1996; Smith, 1997) associated with a direct entrance to a four year university. Following one or more years studying (and possibly competing) at a junior college, students could then transfer to a four year institution whereupon they could (re)commence their involvement in intercollegiate athletics (NCAA, 2011c).

Another explanation for why a student-athlete may be academically delayed is associated with the phenomenon known as "redshirting."2 Typically, intercollegiate athletes participating in NCAA sports are eligible to compete for up to four years, which coincides with how long it ought to take for undergraduate students to complete the requirements to obtain their bachelor's degree. For various reasons, university athletes may wish (and are often required) to delay or suspend their competitive eligibility (typically in their first year) so that they may extend the length of this eligibility period for up to one additional year (Ness \& Colles, 2007).

Redshirting is generally not permissible in high school athletics, as it "is contrary to the educational mission. Furthermore, redshirting creates unfair competition advantages, possible dangerous mismatches, and unwarranted exclusion of peer student-athletes" (Ness \& Colles, 2007, p. 470). Nevertheless, redshirting is quite common in intercollegiate athletics, particularly in sports such as football and basketball where it is used by coaches as a mechanism for stockpiling talent that is not currently needed (Hart-Nibbrig \& Cottingham, 1986; Stiglitz, 1991). Athletes who are redshirted may receive financial aid and are given the opportunity to practice and train with the rest of the team, but are rarely permitted to travel, dress, or compete for the team during their redshirt year (NCAA, 2011a).

Regardless of the reason that an intercollegiate student-athlete could become academically delayed, the outcome is the same: students are entering their first year of university at different ages. The implications of this could make for a very uneven playing field with respect to the opportunities to participate in intercollegiate athletics. While the RAE has traditionally disadvantaged relatively younger athletes, it is less understood how academic timing impacts participation opportunities for student-athletes.

Thus, the purpose of this study is to examine the moderating impact of academic timing on the relative age effect for student-athletes in women's intercollegiate softball. Specifically, we tested the following hypotheses: 
Hypothesis 1: There will be a significant difference in the distribution of birthdates between female intercollegiate softball players and what would be expected within the general population, in support of the RAE.

Hypothesis 2: There will be a significant difference in the distribution of birthdates between female intercollegiate softball players who are "on-time" and what would be expected within the general population, in support of the RAE.

Hypothesis 3: There will be a significant difference in the distribution of birthdates between female intercollegiate softball players who are "academically delayed" and what would be expected within the general population, supporting an inverse of the RAE.

\section{Method}

We examined the 50 top-ranked NCAA Division I women's softball teams at the conclusion of the 2011 season (NCAA, 2011b). This number was chosen due to the preponderance of media attention that these elite teams attract and the increased likelihood that birthdate information would be available for the student-athletes who compete on these teams. Birthdates of players on the end-of-season rosters for each of these top 50 ranked teams were collected, where available, from the official varsity websites of each university. In instances where birthdate information was not publicly available through the varsity websites, the student-athletes from these schools were removed from our sample.

For data analysis purposes, the student-athletes were grouped into birth quartiles based on which month of the year they were born. December 31st was used as the anchor point, as that is the annual cut-off date for dividing players into age groupings within the sport of women's softball (Amateur Softball Association of America, 2012; Little League Softball, 2012). Thus, quartile one (Q1) represented birthdates from January through March, Q2 represented April through June, Q3 represented July through September, and Q4 represented October through December.

The decision to use the birthdate cut-off for the sport (i.e., December 31st), rather than for entrance into kindergarten (which varies considerably over time and from state to state), ${ }^{3}$ is to account for the fact that softball is typically learned in youth leagues and not necessarily in schools. According to Glamser and Marciani (1992), baseball talent is cultivated in community programs, which are based on age and not grade level. The sport of softball is no different in this regard. On the basis that participants take up the sport of softball on a competitive basis years before intercollegiate competition commences, we determined that the sport's generally-accepted cut-off date of December 31st would be most appropriate for our examination.

In addition to grouping the student-athletes into quartiles according to birthdate, they were also identified as being on-time or academically delayed based on their birth year and their eligibility status. Consistent with Glamser and Marciani (1992), we coded student-athletes who commenced their college careers in the year that they turned 18 years of age as being on-time with their class. Thus, first year, sophomore, junior, and senior student-athletes who were born in the years 1992, 1991, 1990, and 1989, respectively, were identified as being on-time with regard to their academic progress. Student-athletes whose eligibility statuses did 
not correspond with these birth years (i.e., they were born one or more years earlier than their eligibility status would indicate) were identified as being academically delayed. Being able to distinguish between student-athletes who are on-time from those who are academically delayed is critical to disentangling the moderating effects of academic timing on the RAE in the context of intercollegiate athletics.

\section{Results}

Unfortunately, not all of the universities that were earmarked for inclusion in our study provided the birthdate information for their student-athletes on their varsity websites. In total, we were successful in collecting birthdate information for 565 intercollegiate softball players, representing 30 of the top 50 teams in the country. Of these 565 student-athletes, $380(67.26 \%)$ of them were deemed to be on-time, with the remaining $185(32.74 \%)$ being identified as academically delayed. The birth years for the female softball players included within our sample extended from 1987 through 1992 (see Figure 1). Consistent with Glamser and Marciani (1992), we found no evidence of athletes who would be classified as being academically advanced.

Chi-square goodness of fit tests $\left(\chi^{2}\right)$ were used to compare the observed distribution of student-athletes' birthdates across quartiles with the expected frequency for each quartile. Many RAE studies rely upon an equal distribution of birthdates across quartiles ( $25 \%$ per quartile) for the expected frequency. This is often done out of convenience or to control for various methodological constraints (e.g., an international sample). Ideally, we would like to have compared the observed distribution of birthdates against those of the overall student populations from which our sample of student-athletes were derived, but this was simply not feasible. In light of these limitations, and in recognition of the fact that over $99 \%$ of the

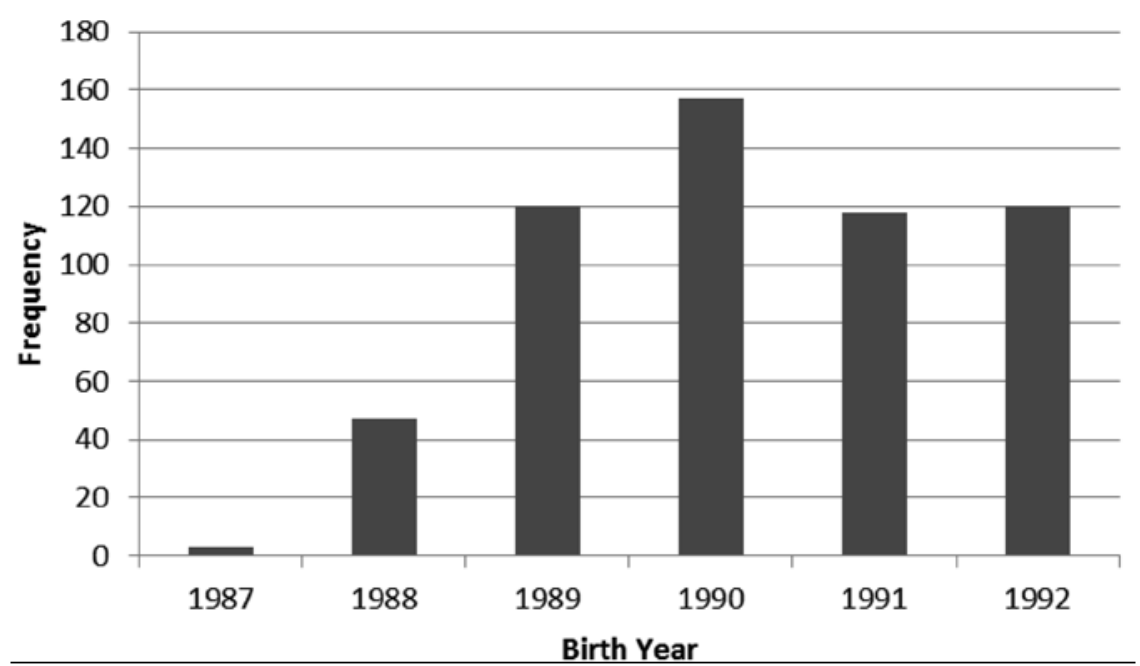

Figure 1 - Frequency of Birth dates by Year. Note: $N=565$. 
student-athletes in our sample were born in the United States, our comparisons were based on the actual distribution of birthdates within the general population using data retrieved from the United States National Center for Health Statistics $(1989,1990,1992,1993 a, 1993 b, 1994)$ for the years 1987 through 1992: Q1 = $23.96 \%, \mathrm{Q} 2=24.84 \%, \mathrm{Q} 3=26.44 \%$, and Q4 $=24.76 \%$.

The distribution of birthdates for the student-athletes listed on the end-of-season rosters of these top-ranked NCAA Division I women's softball teams across the relative age quartiles were significantly different $\left(\chi^{2}=11.17, d f=3, p=.01, \varphi=\right.$ $0.14)$. Specifically, the results revealed a significant over-representation of studentathletes born during Q1 $(28.14 \%, z=2.03)$ and a significant under-representation of student-athletes born in Q3 $(21.59 \%, z=-2.24)$. Consistent with the first hypothesis, this decline in birthdates across quartiles provides initial evidence of the RAE within the context of women's intercollegiate softball (see Figure 2).

In our effort to examine the moderating effects of academic timing on the RAE, we reanalyzed our data using only the student-athletes who were deemed to be on-time. Upon doing so, we revealed even stronger evidence of the $\operatorname{RAE}\left(\chi^{2}=\right.$ 89.34, $d f=3, p<.001, \varphi=0.49)$, with a linear reduction in the number of birthdates over the course of the calendar year. As depicted in Figure 3, the birthdates of the women's softball players who were deemed to be on-time were significantly different from what would have been expected in the general population across all four quartiles, thereby supporting the second hypothesis: $\mathrm{Q} 1=36.05 \%(z=4.82)$, $\mathrm{Q} 2=35.53 \%(z=4.18), \mathrm{Q} 3=20.53 \%(z=-2.24)$, and Q4 $=7.89 \%(z=-6.61)$.

Finally, and in support of our third hypothesis, the data analysis for those student-athletes who were academically delayed revealed a significant inverse of the traditional RAE $\left(\chi^{2}=91.67, d f=3, p<.001, \varphi=.70\right)$. For those who were academically delayed, a linear increase in birthdates was evidenced across quartiles

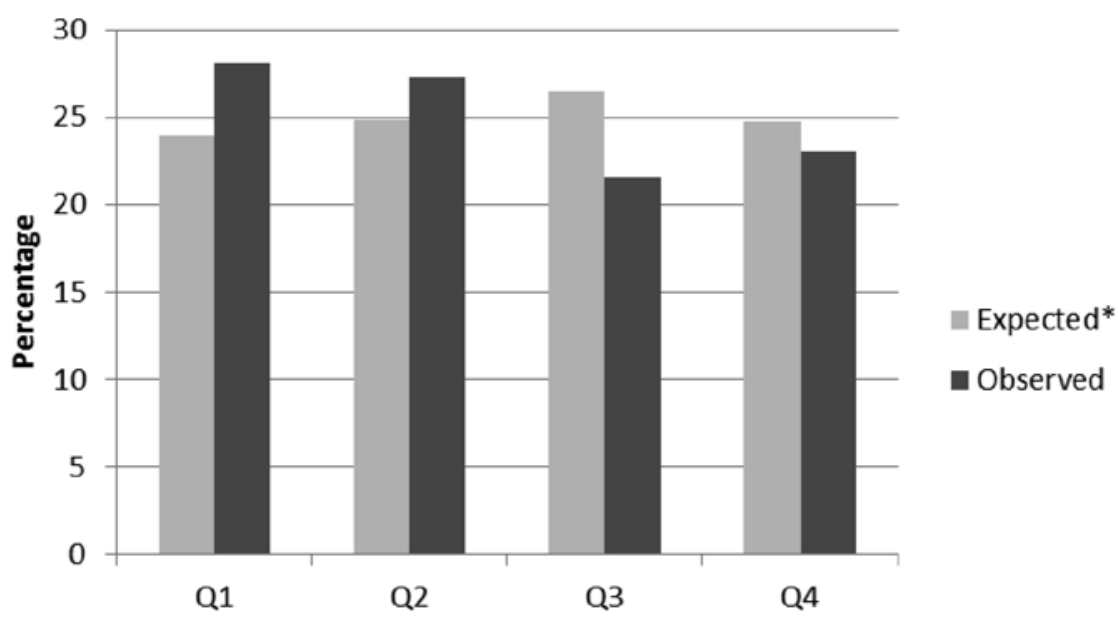

Birth Quartile

Figure 2 - Expected vs. Observed data. Note: $N=565 ; *$ expected values derived from National Center for Health Statistics (1989, 1990, 1992, 1993a, 1993b, 1994). 
(see Figure 4), with an under-representation of student-athletes born during Q1 $(11.89 \%, z=-3.35)$ and Q2 $(10.27 \%, z=-3.98)$, and a dramatic over-representation of student-athletes born in Q4 $(54.05 \%, z=8.009)$. A summary of the results from all statistical analyses is provided in Table 1.

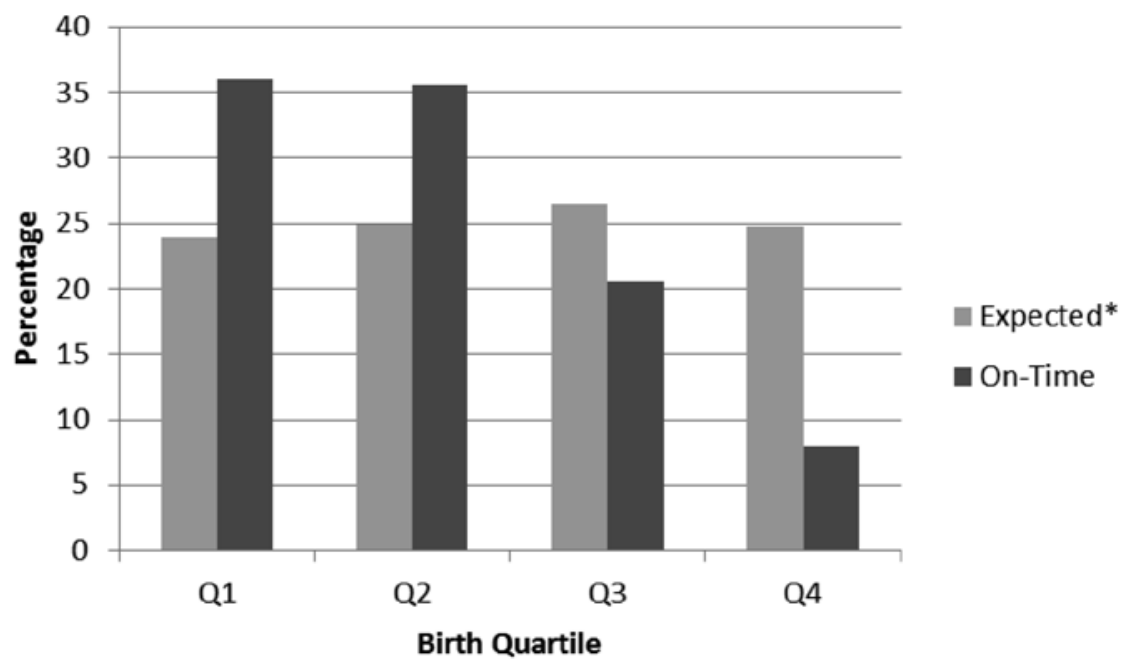

Figure 3 - Expected vs. On-time data. Note: $N=380 ; *$ expected values derived from National Center for Health Statistics (1989, 1990, 1992, 1993a, 1993b, 1994).

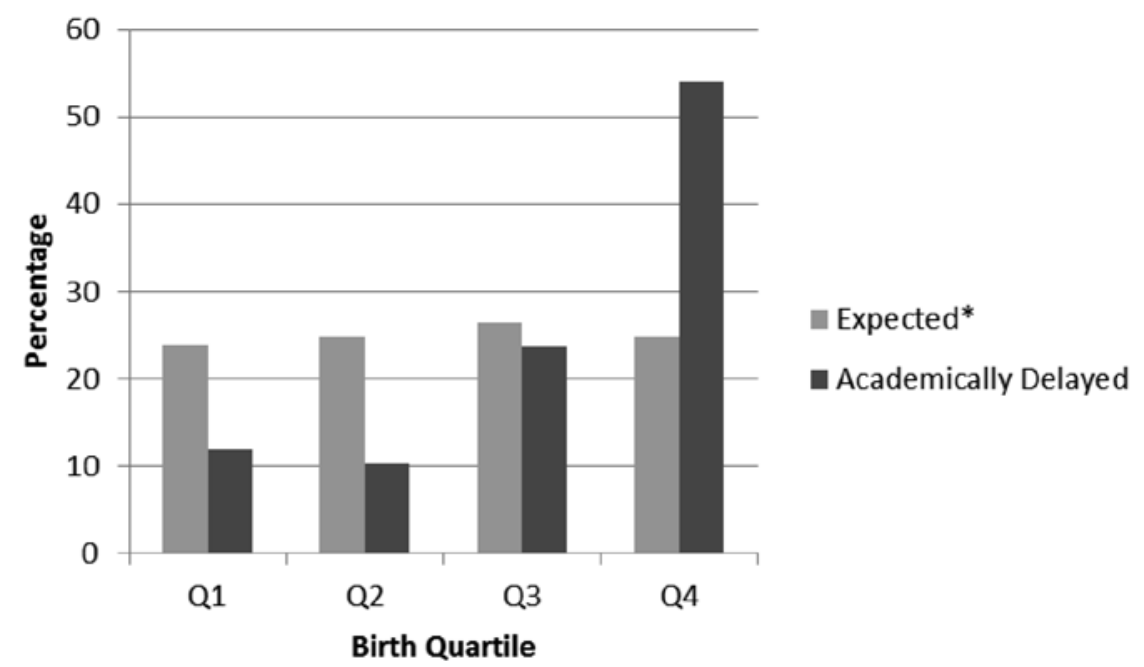

Figure 4 - Expected vs. Academically Delayed data. Note: $N=185$; * expected values derived from National Center for Health Statistics (1989, 1990, 1992, 1993a, 1993b, 1994). 
Table 1 Summary of all Statistical Results.

\begin{tabular}{lccc}
\hline & Total & On-Time & Academically Delayed \\
\hline $\mathrm{N}$ & 565 & 380 & 185 \\
$\chi 2(\mathrm{df})$ & $11.17(3)^{* *}$ & $89.34(3)^{* * *}$ & $91.67(3) * * *$ \\
$\varphi$ & $0.14 \dagger$ & $0.49 \dagger \dagger$ & $0.70 \dagger \dagger \dagger$ \\
Birth Quartile 1 & & & \\
$\%$ & 28.14 & 36.05 & 11.87 \\
$\mathrm{z}$ & $2.03 *$ & $4.82^{* * *}$ & $-3.35 * * *$ \\
Birth Quartile 2 & & & 10.27 \\
$\%$ & 27.26 & 35.53 & $-3.98 * * *$ \\
$\mathrm{z}$ & 1.16 & $4.18^{* * *}$ & \\
Birth Quartile 3 & & & 23.78 \\
$\%$ & 21.59 & 20.55 & -0.70 \\
$\mathrm{z}$ & $-2.24 *$ & $-2.42^{*}$ & \\
Birth Quartile 4 & & & 54.05 \\
$\%$ & 23.01 & 7.89 & $8.01 * * *$ \\
$\mathrm{z}$ & -0.84 & $-6.61 * * *$ & \\
\hline
\end{tabular}

Notes: $*=\mathrm{p}<.05, * *=\mathrm{p}<.01, * * *=\mathrm{p}<.001 ; \dagger=$ small effect size, $\dagger \dagger=$ medium effect size, $\uparrow \dagger \dagger$ $=$ large effect size.

\section{Discussion}

A RAE exists in women's college softball, albeit modest when the data are considered in aggregate. Our findings show an over-representation of players born in the first two quartiles of the year, and an under-representation of players born in quartiles three and four. However, the importance of birth quartile is magnified considerably once academic timing is taken into account. For those who were on-time academically, there were more than four times as many athletes born in quartile one than in quartile four. This pattern was reversed for those who were academically delayed. Within this group, players with quartile four birthdates constituted more than half of the entire sample.

These results both complement and extend existing literature on the RAE in women's sports. In the first sense, we have demonstrated that the RAE is clearly prevalent within the context of women's intercollegiate softball. This outcome is in direct contrast to the only other study to examine the RAE in women's baseball, which found no effect. Abel et al. (2011) attributed their null results to a lack of organized youth leagues at that time. However, times have changed, and so have the number of opportunities for female participation within the sport at both the recreational and competitive levels (Irick, 2011). This increased participation, and the corresponding competition for spots on elite rosters, may have fostered the emergence of RAEs in the sport in recent decades. 
Secondly, studies examining the RAE in intercollegiate athletics have been minimal (Cobley et al., 2009). This study will hopefully spark additional research on the RAE in this relatively neglected competitive sport context. At the same time, this research further emphasizes the need to take into account the moderating effect of academic timing when assessing the RAE within this particular context. It has been more than twenty years since Glamser and Marciani (1992) first introduced the notion of academic timing, but it has received scant attention by researchers since this time. Accounting for academic timing, particularly within the context of intercollegiate athletics, provides an additional level of nuance to our understanding of the RAE.

Over the years, many different solutions to the RAE have been proposed in an effort to reduce or minimize its impact, including: (a) reducing the range of age groupings to minimize the advantage of the older players, (b) rotating cut-off dates so that it is not the same children that are advantaged year after year, and (c) implementing a quota system on competitive teams to ensure balanced representation from all quartiles (Barnsley et al., 1985). Our results suggest that by delaying one's intercollegiate softball career by one year, relatively younger female student athletes may be able to overcome the age bias inherent to the selection process. Redshirting, or other methods of holding students back a year, potentially serves an important purpose by providing relatively younger students with an opportunity to compete, and upholding the NCAA's Principle of Competitive Equity.

While there are advantages to being academically delayed from the standpoint of participating in women's intercollegiate softball, there are potential disadvantages to consider as well. First and foremost, there are opportunity costs associated with being held back an extra year in school, which translate into a delayed entry into the work force and lost wages (Eide \& Goldhaber, 2005). In addition, being academically delayed only benefits relatively younger students provided that their relatively older counterparts do not seek the same advantage. If every prospective student-athlete sought the advantage of being academically delayed, such an advantage would necessarily disappear.

One of the limitations of this work is the difficulty in determining the precise reason that nearly one third of the athletes in our sample were academically delayed. As noted previously, there are many explanations for how a female intercollegiate softball player could become academically delayed, including but not limited to: redshirting in a previous season, failing or repeating an earlier grade level, taking a year off between high school and university, or remaining in high school for an extra year in the form of a victory lap. However, one can also become academically delayed at the beginning of one's academic career, as parents may hold their children back from starting kindergarten for an additional year, in an attempt to provide their children with the benefits of being one of the oldest in their cohort (CBS Interactive, 2012). Future research into the reasons that such students become academically delayed would prove valuable in understanding whether it is part of a deliberate strategy to exploit weaknesses in the selection process or if it is an unintended benefit of being held back at some earlier stage in their academic careers. Furthermore, as this study was specific to women's intercollegiate softball, more research across a variety of women's and men's intercollege athletics is needed to confirm the generalizability of these findings. 


\section{Notes}

1. Although it may be possible for students to enter university with an older age-grouped cohort, the likelihood of these relatively younger students competing on intercollegiate athletic teams is very low. In fact, Glamser and Marciani (1992) found no evidence of these "academically advanced" students competing on the football and baseball teams that they examined.

2. Redshirting has also been used in the RAE literature in reference to the practice of postponing a child's entrance to kindergarten (West, Meek, \& Hurst, 2000).

3. See Colosanti (2007) and Dhuey and Lipscomb (2008) for a more detailed discussion of these variations.

\section{References}

Abel, E.L., Kruger, M.M., \& Pandya, K. (2011). A relative age effect in men's but not women's professional baseball: 1943-1954. Psychological Reports, 109(1), 285-288. PubMed doi:10.2466/05.PR0.109.4.285-288

Allen, J., \& Barnsley, R. (1993). Streams and tiers: The interaction of ability, maturity, and training in systems with age-dependent recursive selection. The Journal of Human Resources, 28(3), 649-659. doi:10.2307/146164

Amateur Softball Association of America. (2012). ASA Code 2012. Retrieved from http:// downloads.asasoftball.com/about/pdf/2012_ASACode.pdf

Armstrong, H.G. (1966). A comparison of the performance of summer and autumn-born children at eleven and sixteen. The British Journal of Educational Psychology, 36, 72-76. PubMed doi:10.1111/j.2044-8279.1966.tb01841.x

Associated Press. (2005, July 9). They'rrre out! Baseball, softball out of Olympics: Sports eliminated for 2012 Games, but could win way back in 2016. Retrieved from http:// nbcsports.msnbc.com/id/8504326/site/21683474/print/1/displaymode/1098/

Barnsley, R.H., \& Thompson, A.H. (1988). Birthdate and success in minor hockey: The key to the NHL. Canadian Journal of Behavioural Science, 20, 167-176. doi:10.1037/ h0079927

Barnsley, R.H., Thompson, A.H., \& Barnsley, P.E. (1985). Hockey success and birthdate: The RAE. Canadian Association for Health, Physical Education, and Recreation, 51, 23-28.

Barrow, H.M., \& McGee, R. (1971). A practical approach to measurement in physical education. Philadelphia, PA: Lea \& Febiger.

Baxter-Jones, A. (1995). Growth and development of young athletes: Should competition levels be age related? Sports Medicine (Auckland, N.Z.), 20, 59-64. PubMed doi:10.2165/00007256-199520020-00001

Baxter-Jones, A., \& Helms, P. (1994). Born too late to win? Nature, 370, 186. PubMed doi: $10.1038 / 370186$ b0

Bedard, K., \& Dhuey, E. (2006). The persistence of early childhood maturity: International evidence of long-run age effects. The Quarterly Journal of Economics, 12(4), 14371472.

Brady, P., \& Allingham, P. (2010). Pathways to university: The "victory lap" phenomenon in Ontario. Canadian Journal of Educational Administration and Policy, 113, 1-25.

Interactive, C.B.S. (2012). Redshirting: Holding kids back from kindergarten. 60 Minutes. Retrieved from http://www.cbsnews.com/8301-18560_162-57390128/redshirtingholding-kids-back-from-kindergarten/?pageNum=5\&tag=contentMain;contentBody.

Cobley, S., Baker, J., Wattie, N., \& McKenna, J.M. (2009a). Annual age-grouping and athlete development: A meta-analytic review of relative age effects in sport. Sports Medicine (Auckland, N.Z.), 39(3), 235-256. PubMed doi:10.2165/00007256-200939030-00005 
Cobley, S., Baker, J., Wattie, N., \& McKenna, J.M. (2009b). How pervasive are relative age effects in secondary school education? Journal of Educational Psychology, 101(2), 520-528. doi:10.1037/a0013845

Colosanti, M. (2007, March). Kindergarten entrance ages: A 30 year trend analysis. Education Commission of the States. Retrieved from http://inpathways.net/kindergarten_trend_analyses.pdf

Côté, J., Macdonald, D.J., Baker, J., \& Abernethy, B. (2006). When "where" is more important than "when": Birthplace and birthdate effects on the achievement of sporting expertise. Journal of Sports Sciences, 24, 1065-1073. PubMed doi:10.1080/02640410500432490

Delorme, N., Boiché, J., \& Raspaud, M. (2010). Relative age effect in female sport: A diachronic examination of soccer players. Scandinavian Journal of Medicine \& Science in Sports, 20, 509-515. PubMed

Delorme, N., \& Raspaud, M. (2009a). Is there an influence of relative age on participation in non-physical sports activities? The example of shooting sports. Journal of Sports Sciences, 27(10), 1035-1042. PubMed doi:10.1080/02640410902926438

Delorme, N., \& Raspaud, M. (2009b). The relative age effect in young French basketball players: A study on the whole population. Scandinavian Journal of Medicine \& Science in Sports, 19, 235-242. PubMed

Dhuey, E., \& Lipscomb, S. (2008). What makes a leader? Relative age and high school leadership. Economics of Education Review, 27, 173-183. doi:10.1016/j.econedurev.2006.08.005

Dickenson, D.J., \& Larson, J.D. (1963). The effects of chronological age in months on school achievement. The Journal of Educational Research, 56, 492-493.

Dixon, J., Horton, S., \& Weir, P. (2011). Relative age effects: Implications for leadership development. International Journal of Sport and Society, 2(2), 1-15.

Edgar, S., \& O'Donoghue, P. (2005). Season of birth distribution of elite tennis players. Journal of Sports Sciences, 23, 1013-1020. PubMed doi:10.1080/02640410400021468

Eide, E.R., \& Goldhaber, D.D. (2005). Grade retention: What are the costs and benefits? Journal of Education Finance, 31(2), 195-214.

Elder, T.E., \& Lubotsky, D.H. (2009). Kindergarten entrance age and children's achievement: Impacts of state policies, family background, and peers. The Journal of Human Resources, 44(3), 641-683. doi:10.1353/jhr.2009.0015

Freyman, R. (1965). Further evidence on the effect of date of birth on subsequent school performance. Educational Research, 8, 58-64. doi:10.1080/0013188650080105

Gladwell, M. (2008). Outliers: The story of success. New York, NY: Little, Brown and Company.

Glamser, F.D., \& Marciani, L.M. (1992). The birthdate effect and college athletic participation: Some comparisons. Journal of Sport Behavior, 15(3), 227-238.

Goldschmied, N. (2011). No evidence for the relative age effect in professional women's sports. Sports Medicine (Auckland, N.Z.), 41(1), 87-88. PubMed doi:10.2165/11586780000000000-00000

Grondin, S., Deshaies, P., \& Nault, L.P. (1984). Trimestres de naissance et participation au hockey et au volleyball. La Revue Québecoise de l'Activité Physique, 2, 97-103.

Grondin, S., \& Koren, S. (2000). The relative age effect in professional baseball: A look at the history of Major League Baseball and the current status in Japan. Avante, 6, 64-74.

Hart-Nibbrig, N.E., \& Cottingham, C. (1986). The political economy of college sports. Lexington, MA: Lexington Books.

Helsen, W.F., Van Winckel, J., \& Williams, M.A. (2005). The relative age effect in youth soccer across Europe. Journal of Sports Sciences, 23, 629-636. PubMed doi:10.1080/02640410400021310

Irick, E. (2011, October). NCAA sports sponsorship and participation rates report: Studentathlete participation 1981-82 - 2010-11. Retrieved from http://www.ncaapublications. com/productdownloads/PR2012.pdf 
Levey, J. (2011). Myth no. 1: The relative-age effect. Sports Illustrated, 115(5), 49.

Little League Softball. (2012). 2012 Little League age chart. Retrieved from http://www. littleleague.org/Assets/forms_pubs/AgeChartBBandSB.pdf

Martin, R.P., Foels, P., Clanton, G., \& Moon, K. (2004). Season of birth and is related to child retention rates, achievement, and rate of diagnosis of specific LD. Journal of Learning Disabilities, 37, 307-317. PubMed doi:10.1177/00222194040370040301

Medic, N., Young, B.W., Starkes, J.L., Weir, P., \& Grove, J. (2009). Gender, age, and sport differences in relative age effects among U.S. masters swimming and track and field athletes. Journal of Sports Sciences, 27, 1535-1544. PubMed doi:10.1080/02640410903127630

Montelpare, W.J., Scott, D., \& Pelino, M. (2000). Tracking the relative age effect across minor, amateur and professional ice-hockey leagues. In A.B. Ashare (Ed.), Safety in ice hockey (Vol. 3, pp. 250-260). Philadelphia, PA: American Society for Testing and Materials.

Musch, J., \& Grondin, S. (2001). Unequal competition as an impediment to personal development: A review of the relative age effect in sport. Developmental Review, 21, 147-167. doi:10.1006/drev.2000.0516

Musch, J., \& Hay, R. (1999). The relative age effect in soccer: Cross-cultural evidence for a systematic discrimination against children born in late competition year. Sociology of Sport, 16, 54-64.

National Center for Health Statistics. (1989, June). Public use data tape documentation: 1987 detail natality. Retrieved from ftp://ftp.cdc.gov/pub/Health_Statistics/NCHS/ Dataset_Documentation/DVS/natality/Nat1987doc.pdf

National Center for Health Statistics. (1990, August). Public use data tape documentation: 1988 detail natality. Retrieved from ftp://ftp.cdc.gov/pub/Health_Statistics/NCHS/ Dataset_Documentation/DVS/natality/Nat1988doc.pdf

National Center for Health Statistics. (1992, August). Public use data tape documentation: 1989 detail natality. Retrieved from ftp://ftp.cdc.gov/pub/Health_Statistics/NCHS/ Dataset_Documentation/DVS/natality/Nat1989doc.pdf

National Center for Health Statistics. (1993a, April). Public use data tape documentation: 1990 detail natality. Retrieved from ftp://ftp.cdc.gov/pub/Health_Statistics/NCHS/ Dataset_Documentation/DVS/natality/Nat1990doc.pdf

National Center for Health Statistics. (1993b, August). Public use data tape documentation: 1991 detail natality. Retrieved from ftp://ftp.cdc.gov/pub/Health_Statistics/NCHS/ Dataset_Documentation/DVS/natality/Nat1991doc.pdf

National Center for Health Statistics. (1994, September). Public use data tape documentation: 1992 detail natality. Retrieved from ftp://ftp.cdc.gov/pub/Health_Statistics/NCHS/ Dataset_Documentation/DVS/natality/Nat1992doc.pdf

National Collegiate Athletic Association. (2011a). Division. Man, XXX, 2011-2012 Retrieved from http://www.ncaapublications.com/productdownloads/D112.pdf.

National Collegiate Athletic Association. (2011b, June 14). NCAA Division I softball rankings. Retrieved from http://www.ncaa.com/rankings/softball/d1/rpi

National Collegiate Athletic Association. (2011c, August). Transfer 101: Basic information you need to know about transferring to an NCAA college (2011-12). Retrieved from http://www.ncaapublications.com/productdownloads/TGONLINE2011.pdf [AUQ5]

National Collegiate Athletic Association. (2012). About the NCAA. Retrieved from http:// www.ncaa.org/wps/wcm/connect/public/NCAA/About+the+NCAA/

National Pro Fastpitch. (n.d.). NPF history. Retrieved from http://www.profastpitch.com/ about/history/

Ness, R.G., \& Colles, C. (2007). Voluntary associations and eligibility issues. In D.J. Cotton \& J.T. Wolohan (Eds.), Law for recreation and sport managers (4th ed., pp. 467-477). Dubuque, IA: Kendall/Hunt Publishing Company.

Popp, N., Hums, M.A., \& Greenwell, T.C. (2009). Do international student-athletes view the purpose of sport differently than United States student-athletes at NCAA Division I universities? Journal of Issues in Intercollegiate Athletics, 2, 93-110. 
Sanders, L., \& Burton, J.D. (1996). From retention to satisfaction: New outcomes for assessing the freshman experience. Research in Higher Education, 37, 555-567. doi:10.1007/ BF01724938

Shakib, S. (2003). Female basketball participation: Negotiating the conflation of peer status and gender status from childhood through puberty. The American Behavioral Scientist, 46, 1405-1422. doi:10.1177/0002764203046010008

Smith, S.E. (1997). High school to college transition: An intervention to reduce student anxiety. Journal of College Admission, 157, 8-15.

Sporting Goods Manufacturers Association. (2010). Sports participation in America. Retrieved from http://www.sgma.com

Stiglitz, J. (1991). NCAA-based agent regulation: Who are we protecting? North Dakota Law Review, 67, 215-226.

Thompson, A.H., Barnsley, R.H., \& Dyck, R.J. (1999). A new factor in youth suicide: The relative age effect. Canadian Journal of Psychiatry, 44(1), 82-85. PubMed

Thompson, A.H., Barnsley, R.H., \& Stebelsky, G. (1991). "Born to play ball”: The relative age effect and Major League Baseball. Sociology of Sport Journal, 8, 146-151.

Thompson, A. H., Barnsley, R. H., \& Stebelsky, G. (1992). Baseball performance and the relative age effect: Does Little League neutralize birthdate selection bias? Nine: A Journal of Baseball History and Culture, 1, 19-30.

Vincent, J., \& Glamser, F.D. (2006). Gender differences in the relative age effect among US Olympic development program youth soccer players. Journal of Sports Sciences, 24, 405-413. PubMed doi:10.1080/02640410500244655

Wallingford, E.L., \& Prout, H.T. (2000). The relationship of season of birth and special education referral. Psychology in the Schools, 37, 379-384. doi:10.1002/15206807(200007)37:4<389::AID-PITS9>3.0.CO;2-K

Wattie, N., Baker, J., Cobley, S., \& Montelpare, W.J. (2007). A historical examination of relative age effects in Canadian hockey players. International Journal of Sport Psychology, 38, 178-186.

Wattie, N., Cobley, S., \& Baker, J. (2008). Towards a unified understanding of relative age effects. Journal of Sports Sciences, 26, 1403-1409. PubMed doi:10.1080/02640410802233034

Weir, P.L., Smith, K.L., Paterson, C., \& Horton, S. (2010). Canadian women's ice hockey evidence of a relative age effect. Talent Development and Excellence, 2(2), 209-217.

West, J., Meek, A., \& Hurst, D. (2000, June). Children who enter kindergarten late or repeat kindergarten: Their characteristics and later school performance (NCES No. 2000-039). U.S. Department of Education, National Center for Education Statistics. Retrieved from http://nces.ed.gov/pubs2000/2000039.pdf 